\title{
Helcococcus sueciensis
}

National Cancer Institute

\section{Source}

National Cancer Institute. Helcococcus sueciensis. NCI Thesaurus. Code C86880.

A species of facultatively anaerobic, Gram positive, cocci shaped bacteria assigned to the phylum Firmicutes. This species is catalase negative, nonsporulating, forms acid from trehalose and lactose and produces alkaline phosphatase and N Acetyl b glucosaminidase. 